\title{
Is capitalism structurally indifferent to gender?: Routes to a value-theory of reproductive labour
}

\author{
Andreas Bieler and Adam David Morton*
}

\begin{abstract}
The contributions of Ellen Meiksins Wood to social property relations arguments have facilitated an enhanced understanding of the historical specificity of capitalism and its structuring conditions. Yet such arguments also have some questionable assumptions when it comes to theorising gender and so-called "extra-economic" identities, most noticeably regarding capitalism as indifferent to gender relations. This article delves into such issues by delivering a set of quandaries about various aspects of the social property relations approach and its relevance to wider debates on economy and space. We contend that debates in Marxism Feminism and social reproduction theory therein should be elevated to centre stage in considerations of political economy and economic geography. Consequently, it is possible to dispense with the notion that capitalism is structurally indifferent to gender, which mars the social property relations approach. At the same time, however, there are tensions within Marxism Feminism, not least revolving around questions of value, the role of unpaid labour in the household, and wider theorising on the relationship between "market" conditions and extra-economic relations of "state" power. We explore two major contending routes to what we call a value-theory of reproductive labour within Marxism Feminism and conclude that this reconnaissance provides an opportunity to initiate enhanced discussion on future political struggles against capital's requirements.
\end{abstract}

Keywords: Marxism Feminism, gender, social property relations, social reproduction theory, value-theory

Ellen Meiksins Wood has made crucial contributions to the social property relations approach, a distinctive historical materialist perspective on capitalism as a system of social relations and

\footnotetext{
"Paper presented at the international workshop 'Revisiting the "Mode of Production": Enduring Controversies over Labour, Exploitation and Historiographies of Capitalism', Centre for the Study of Social and Global Justice (CSSGJ), University of Nottingham (1 July 2019) and at the $12^{\text {th }}$ Australian International Political Economy Network (AIPEN) workshop, University of Queensland, Brisbane (15-16 July 2021). Much of the research in this paper was explored through pedagogy. Andreas Bieler thanks his students on the second-year module M12089 'IPE and Global Development' and the third-year module M130HF 'Globalisation and Resistance' at the University of Nottingham. Adam David Morton would like to thank his undergraduate students in the Department of Political Economy at the University of Sydney, enrolled in ECOP2012 'Foundations of Modern Capitalism' and the Honours unit ECOP4011, 'Advanced Theory in Political Economy' for their acumen and co-questioning. Both our teaching has directly fed into the research for this paper. We would also like to thank Sirma Altun, Gareth Bryant, Elizabeth Hill, Chris Hesketh, Madelaine Moore, Jörg Nowack, the Marxism Reading Group and the Past \& Present Reading Group as well as the three reviewers and editor Susanne Soederberg for this journal for earlier feedback on our arguments.
} 
political power relevant to understanding economy and space. By highlighting the importance of the organisation of production in capitalism, revolving around wage labour and the private ownership or control of the means of production, Wood enables us to comprehend the historical specificity of capitalism and why the "political" and the "economic", the "state" and the "market", appear as separate (e.g. Wood 1995: 31-6; Wood 1994: 25). Unlike in feudal social relations of production, for example, where the extraction of economic surplus is directly politically enforced and the political overlaps with the economic, capitalism uniquely does not exploit labour-power through explicit coercion or exclusive reliance on the coercive wielding of power by the state. Instead, the extraction of surplus-value is economically and indirectly enforced by the sale of labour-power mediated by the market. These relations thus constitute the separate appearance of the "state" and the "market" in capitalism, with these forms of appearance then coming to shape the key units of analysis within the orthodoxy of mainstream political economy arguments and its ahistorical underpinnings (Bieler and Morton 2018: 7-8). Further, Wood's emphasis on the social property relations approach helps to identify the key structuring conditions of capitalist social relations of production. It is not only the possessors of labour-power that are compelled to offer for sale, as a commodity, their labour for a wage. The destiny of the owners of the means of production is also one defined by a compulsion to extort the maximum surplus-value from producers in order to accumulate and survive. This is why capitalism induces a mode of compulsion not based on personal relations of domination. Due to the same compulsions to accumulate it also results periodically in crises of overproduction or overaccumulation. Therefore, in the attempts to overcome crisis, capitalism is underpinned by relentless pressure towards outward expansion along uneven and combined developmental lines in the search for profit and growth maximisation based on surplus-value production and realisation (Bieler and Morton 2018: 38-41). As Wood summarises:

The class relation that constitutes capitalism is not, after all, just a personal identity, nor even just a principle of "stratification" or inequality. It is not only a specific system of power relations but also the constitutive relation of a distinctive social process, the dynamic of accumulation and the self-expansion of capital (Wood 1995: 246). 
The focus on social property relations, however, has increasingly led to criticisms of too narrow a focus on the exploitation of wage labour in commodity production, overlooking the importance of gendered and racialised forms of oppression in processes sustaining capital accumulation. In other words, the social property relations approach delivers decidedly contentious standpoints on human emancipation and the role of gender, race, and class struggles within and against capitalism. With a deeply spatial metaphor, it is argued that the "economic" terrain is 'the home ground of class struggle' and that, from the point of view of capital, social reproduction and households constitute the private sphere of the family (Wood 1988: 4, 8). Hence, 'the first point about capitalism is that it is uniquely indifferent to the social identities of the people it exploits' (Wood 2002b: 278). For this reason, Wood argues that there is a structural indifference of capitalism to "extra-economic" identities, meaning that a world of gender equality and racial equality could be logically envisaged without portending the end of capitalism. To cite Wood again (1988: 8; 1995: 270), 'capitalism could survive the eradication of all oppressions specific to women as women-while it would not, by definition, survive the eradication of class exploitation'. From this social property relations standpoint, it is argued that there is no specific structural necessity for gender oppression in capitalism and that capitalism is uniquely indifferent to the social identities of the people it exploits (Wood 1988: 5; Wood 1995: 266). Yet, is capitalism structurally indifferent to gender? This becomes the central burgeoning question that animates this article.

Stressing the constitutive historical specificity of capitalism is pivotal to bringing into sharp relief the formative moments of market-mediated conditions of exploitation that result in the separate allocation to the "private" economic sphere of appropriation and the "public" sphere of the state as the ultimate locus of coercive power. To structure our analysis in this article, then, a first section delves into the innovative arguments of the social property relations approach crafted by Ellen Meiksins Wood to trace a unique lineage of social reproduction theory on the spatial differentiation of "economic" and "political" power within capitalism. At the same time, we also raise a series of broader quandaries about the social 
property relations viewpoint, including its problematic position on the role of patriarchy in capitalism and the controversies surrounding the argument that capitalism is indifferent to gender inequalities. A second section then embarks on a wider discussion of the internal relationship between capitalist exploitation and patriarchal oppression. Recent interventions in decolonial theory have asserted dialectical theorisation to address the multiple oppressions that work through gender, race, sexuality and class as internally constitutive. In an attempt to avoid the subsumption of race to class, however, there has been the jettisoning of an explicit focus on 'gender identity' relegating it, instead, as a category that is, at best, held alongside class, race, nation and people (Ciccariello-Maher 2017: 173n.11). The result of this radicalised approach to the dialectic of decolonisation is that it leaves little space to address the economic geographies and histories of patriarchy and the dependence of capitalism on the body and, especially, the work of women (see Orzeck 2007). Conceiving relations as externally associated based on their ontological exteriority, results in a view of political identity as made up of independent, relatively isolated and static, reified forms that then merit analysis only when they enter into contact with each other (Bruff 2011: 85; Morton 2013: 139-43). By contrast, the hallmark of historical materialism is a process of abstraction based on dialectics and a philosophy of internal relations, or the way the whole is present through the inner connection of each moment or aspect. As Bertell Ollman (1976: 61) avers, 'the dialectical method of inquiry is best described as research into the manifold ways in which entities are internally related' (see also McNally 2015). Extended by Ariel Salleh (1997/2017: 245), the Marxist dialectical development of feminism necessarily means that 'a new mode of abstraction is called for in the process of reconstructing our historically deleted human identity with/in nature'. From this perspective, the negation of dualisms entails charting a dialectical zigzag course through the materially embodied economic geographies of gendered, racialised, decolonised and classed dynamics within the wider web of nature and ecological relations (Salleh 1997/2017: 130, 279). Our second section, then, will engage with work on the 'social 
factory' within Marxist Feminist social reproduction theory to analyse how these internal relations can be conceptualised.

While Marxist Feminist perspectives link the spheres of production and social reproduction in sustaining capitalist accumulation, there exist clear tensions within such contributions on the extent to which social reproduction directly (or only indirectly) contributes to surplus-value creation. Under a rubric that we categorise as a value-theory of reproductive labour our aim in the third section is to highlight these existing tensions within Marxist Feminism, defining radical political economy and economic geography debates. The goal is not to adjudicate between or synthesise these contending perspectives within a single valuetheory of reproductive labour defining Marxism Feminism. Rather, we argue that a subtler appreciation of the contending approaches in Marxism Feminism to the social reproduction of labour power from a value-theory of reproductive labour standpoint, throws into relief competing positionalities on the value question and the issue of alternative political forms of struggle. Highlighting the pivotal role of women as producers and reproducers of the most essential capitalist commodity, namely labour-power, is a crucial initial step within accounts on the history and ongoing necessity of primitive accumulation to capitalism. Beyond that, though, our argument is that by recognising diverging positionalities on the value-theory of reproductive labour question within Marxism Feminism it is possible to throw into relief the distinguishing issues of political struggle. Our aim is, thus, to expose further those tensions on the value-theory of reproductive labour issue as a platform for future discussions on political struggle against capital's requirements.

\section{On the spatial differentiation of "economic" and "political" power}

According to Suzanne de Brunhoff, capitalism implies a differentiation of the private sphere (the economy) from a public sphere (political power). This is due to the specific character of the social relations of production within capitalism, so that the state appears as a public sanction external to forms of economic policy (de Brunhoff 1978: 66-7). Of course, the state 
is actually immanent in economic policy-whether through management of the commodity labour-power or money capital-but nevertheless the public sanction of state power appears as a technical precondition 'whose application presents purely technical problems of "finetuning"', in terms of fiscal policy, monetary policy, or social policy (de Brunhoff 1978: 80). Norms of regulating capitalism then rotate around principles of depoliticisation, referring to the removal from the sphere of public debate-in parliamentary institutions and regulatory public control-economic problems, including the "privatisation" of industrial or finance sectors (de Brunhoff 1978: 98). Forms of economic policy and state economic management then circulate through the superintendence of labour-power and money capital with the expansion of market-based preconditions and policies giving rise not to the abolition, removal, or retreat of the role of the state but a change in presence of the form of state management. This position on the spatial differentiation of the "economic" and the "political" in capitalism comes to denote social property relations arguments. Within capitalism, economic mechanisms mediated through dependence on market imperatives appear as constituted externally from the coercive powers of the state. 'At best', argues Ellen Meiksins Wood (1995: 21), 'a spatially separate political power may intervene in the economy, but the economy itself is evacuated of social content and depoliticised'. How has this spatial differentiation of the "economic" and the "political" in capitalism become constituted historically? To what extent is there a separation of the "private" moments of surplus appropriation mediated by market compulsion from the "public" moments of coercive institutions, such as in the form of the state, in contemporary processes of capital accumulation?

To highlight the historically specific spatial differentiation of the "economic" and the "political" in capitalism a contrast is drawn between the social property relations that inhered within feudalism with those deemed to mark capitalist society. Within the feudal system agrarian property was privately controlled by a class of feudal lords who extracted a surplus from the peasants by politico-legal relations of compulsion: "extra-economic" coercion was articulated through means of labour services, rents in kind, or customary dues owed to the 
individual lord by the peasant. Feudalism therefore involved a fusion of the juridical serfdom and military protection of the peasantry by a social class of nobles exercising a monopoly of law and private rights of justice within a framework of fragmented sovereignty (see Anderson 1974a: 150-1; Anderson 1974b: 404-7). Within feudalism this fusion of the "economic" and the "political" meant that there was a unity of surplus extraction, military domination, and class rule. Accordingly, what distinguished the feudal mode of production in Europe, following Perry Anderson, was the specific organisation of seigneurial and serf classes in a vertically articulated system of parcellised sovereignty and scalar property. 'It was this concrete nexus', he notes, 'which spelt out the precise type of extra-economic coercion exercised over the direct producer' (Anderson 1974b: 408). These pre-capitalist property relations shaped early state formation, so that 'the parcellised sovereignty of feudalism represented a network of very local and personal social relations, which were at once political and economic', giving way to more centralised monarchies and absolutist territorial states (Wood 2002a: 168; Wood 2003: 37). Hence, 'the "modern" state, together with "modern" conceptions of territoriality and sovereignty, emerged out of social relations that had nothing to do with capitalism' (Wood 2002a: 173).

Under capitalist social property relations the direct extraction of surplus is accomplished through "non-political" relations associated with different forms of social power. In capitalist social forms, surplus extraction is indirectly conducted through a contractual relation mediated by dependence on market mechanisms between those who maintain the power of appropriation, as owners of the means of production, over those who only have their labour to sell, as expropriated producers. Put most starkly, as a consequence, 'in capitalism, there is a complete separation of private appropriation from public duties' (Wood 1995: 31). The direct producers are thus no longer in possession of their own means of subsistence but are compelled to sell their labour-power for a wage in order to gain access to the means of production (Wood: 1995: 31-6). 'Only in capitalism is the dominant mode of appropriation based on the complete dispossession of direct producers, who . . . are legally free and whose 
surplus labour is appropriated by purely "economic" means' (Wood 2002a: 96). Said otherwise, direct producers only have access to the means of production through the sale of their labour-power in exchange for a wage, which is mediated by the purely "economic" mechanisms of the market. The market, in this focus on social property relations, does not therefore represent an opportunity but, rather, a compulsion to which both appropriators (capital) and expropriators (labour) are subjected, through the imperatives of competition, labour productivity, profit-maximisation, and survival. Here 'the dictates of the capitalist market-its imperatives of competition, accumulation, profit-maximisation, and increasing labour productivity-regulate not only all economic transactions but all social relations in general' (Wood 2002a: 7, emphasis added; Wood 1994).

The origin of capitalism-the displacement of "politically" constituted property by "economic" power-is linked to the historical process of primitive accumulation signifying the reconstitution of peasants in possession of the means of subsistence into propertyless individuals compelled to sell their labour. This was 'the historical process of divorcing the producer from the means of production' leading to a situation in which 'capitalist production stands on its own feet' (Marx 1867/1990: 874, 875). Embroiled in this violent transformation of blood into capital, the historical rupture of primitive accumulation means:

the transformation of the individualised and scattered means of production into socially concentrated means of production, the transformation, therefore, of the dwarf-like property of the many into the giant-like property of the few, and the expropriation of the great mass of the people from the soil, from the means of subsistence and from the instruments of labour, this terrible and arduously accomplished expropriation of the mass of the people forms the pre-history of capital (Marx 1867/1990: 928).

Robert Brenner argues that it was in medieval England that the process of enclosures heralded what Marx refers to as primitive accumulation resulting in the transition to capitalism based on a specific set of social property relations linked to a landlord/capitalist tenant/wagelabourer structure (Brenner 1985: 46-9). Thus, in the "transition debate" and the historically peculiar case of state formation in England, the development of capitalism and the state were intertwined or in tandem. In England 'state formation took the form of a cooperative project, a kind of division of labour between political and economic power, between the monarchical 
state and the aristocratic ruling class, between a central political power that enjoyed a virtual monopoly of coercive force . . . and an economic power based on private property in land more concentrated than elsewhere in Europe' (Wood 2002a: 172). By contrast, in different places across continental Europe, capitalism was "born into" the prior system-of-states (Wood 1991: 26). It was propelled through an anterior states-system configured by conditions of uneven and combined development as a structuring principle of "the international" (Lacher 2006; Teschke 2003). The differentiation of the moment of appropriation through market imperatives from the moment of coercion in the state, in so doing, allocated two distinct complementary spheres, with capital having a unique capacity for spatial expansion (Wood 2002a: 177-8). The spatially fragmented order of multiple states has nevertheless remained an assiduous feature of the uneven development of capitalism, with global capital advancing rather than dissolving the unevenness of state territoriality and political space (Wood 2002a: 180-1; Wood 2006: 25-6). Locally, the rise of the "public" sphere of the state and the "private" sphere of capitalist property marked by market imperatives, which appear detached, has become consolidated by accumulation on a global scale. As Wood states:

It is certainly true that in capitalist society, with its separation of "political" and "economic" spheres, or the state and civil society, coercive public power is centralised and concentrated to a greater degree than ever before, but this simply means that one of the principal functions of "public" coercion by the state is to sustain "private" power in civil society (Wood 1995: 255).

In summary, one of the major features of merit in this analysis of historically specific property relations is the recognition of the role of the state in sustaining accumulation. Extra-economic "political" power prevails as the ultimate arbiter while accumulation proceeds through autonomous "economic" forms, which is affirmed through a specific spatial grammar that makes legible the conditions of uneven development constituting the nexus between the "state" and the "market" within capitalism (Wood 2006: 13, 24). As Marx (1861-63/2000, Part III: 271-2), in Theories of Surplus Value concludes, 'once capital exists, the capitalist mode of production itself evolves in such a way that it maintains and reproduces this separation on a constantly increasing scale'. 
The intonation of a social property relations approach to focus on the historical specificity of the dictates of the capitalist market and its compulsions of competition, profitmaximisation, accumulation and increased labour-productivity is compelling. Indeed, the contribution of Ellen Meiksins Wood to understanding the capitalist market as an imperative rather than an opportunity in relation to the origin of capitalism and then the representation of the separation of the "state" from the "market" in the ongoing autonomisation of the "economic" from the "political" is pivotal. Equally, how these economic imperatives were founded in an ideology of improvement-linked to the early-modern economic theory of William Petty and John Locke-as the basis for property rights to increase labour productivity, enhance exchange-value, and ensure enclosure and dispossession should be recognised as one of her richest contributions. How the ideology of improvement, based on making land productive-governed by a logic of abstraction, calculation and measurement through land surveys-to understand how property laws were constituted through agrarian capitalism in England and also through wider settler-colonial spaces is one of her unique singular contributions. This focus on how agrarian land in England was "improved" and transformed into an income-yielding investment of exchange-value to shape not only agrarian property but also its rural aesthetic based on productivity and profit suffuses this social history of political thought. It is also significant that this focus on the ideology of improvement is permeated with insights on the emerging ideas of racial difference in the spaces of the settlercolony, from Ireland to wider overseas expansion in North America and beyond (Wood 1991; Wood 2002a; Wood 2003; Wood 2012; Wood and Wood 1997).

Yet the constant invocation to focus on conditions of market-dependence, capitalist imperatives of competition, compulsions of accumulation, profit-maximisation and increasing labour-productivity does have the tendency to collapse into a mantra of abstractions rather than an explanation of actual history. As Jairus Banaji (2010: 54) reports, 'in a methodology of forced abstractions, which identified relations of production with particular forms of exploitation, the concept of "historical specificity" was radically impoverished.' Three 
quandaries arise from the mantra-making of abstraction that emerges on agrarian capitalism. First, flowing from the commitment to "economic" and "political" spatial differentiation is a creeping binary dualism where the analytical distinction becomes a formal separation. The moment of coercion and the moment of appropriation, rather than spatially differentiated, become separated as two distinct spheres (Wood 2002a: 177-8). Equally, the social property relations of feudalism and capitalism are often presented in a binary fashion, rather than addressing the prevalence of hybrid labour systems within the uneven developmental geographies of capitalism. For Wood (1995: 30), 'the "economic" power of appropriation possessed by the capitalist is separated from the coercive political instruments'. This is despite the confusing confessional slippage that she makes in relation to agrarian capitalism that, 'people could be market-dependent-dependent on the market for the basic conditions of their self-reproduction-without being completely dispossessed' (Wood 2002a: 130-1). As Sébastien Rioux has powerfully relayed to economic geography scholars, the abstractions of the "economic" and the "political" in capitalism come to be externally-related categories so that:

The functional separation between an "economic economy" and a "political state" suggests more of a failure to analyse the internal relations between the two "moments" than the identification of what the theory considers to be a fundamental contradiction of capitalism (Rioux 2013: 107).

Thus, the knotty internal relation between unfree labour and wage-labour producing surplusvalue as a pillar of capitalist accumulation is explained away. The dichotomy of unfree/free labour and its association with the binary of pre-capitalist/capitalist social property relations is, for sure, a question of historical development. Yet the social property relations approach separates out and downplays the role of forms of labour on slave-plantations, sharecropping, chattel-slavery, or hybrid labour-tenancy on estate-systems in constituting circuits of capital accumulation on a word-scale. While wage labour is the dominant form of exploitation in capitalism, it is not the only one with forms of exploitation from previous modes of production continuing to co-exist. Yet, the violence of these abstractions-where the separations become severely simple fetishisms of economic forms and phenomena (Sayer 1987: 140)-also have 
a contemporary detrimental consequence. In the twenty-first century, a conservative estimate is that there are more than 21 million people living in conditions of forced labour, or modern slavery, subjected to direct coercion in feeding sources of value-creation, generating more than $\$ 150$ billion in "illegal profit" (ILO 2014: 1, 45). Instances of direct coercive force in sex-trafficking, human-trafficking, resource extraction, agricultural cultivation or in the production of commodity forms including illegal drug substances are all part and parcel of contemporary capitalism. Here the unity of appropriation and coercion is bleakly evident within really existing capitalism today rather than their separation.

Second, in asserting the systemic unity of capitalism there is a totalising logic so that capital is spatially deemed to dominate all areas of social life from production to appropriation. The market dependence induced by capitalism and its imperatives and compulsions of competition, accumulation, profit-maximisation and increasing labour productivity are again held regnant. These classifications are themselves taken as omnipresent and residual categories so that they 'regulate not only all economic transactions but social relations in general' (Wood 2002a: 7: Wood 1994: 15). Capitalism and 'its capacity to penetrate every aspect of social life' is, according to Wood, so pervasive that 'there is hardly an aspect of life in capitalist society that is not deeply determined by the logic of the market' (Wood 1995: 245, emphasis added, and 280). The problem here is one of capitalocentrism, referring to a view that unduly reinforces the apparent strength of capitalism and downplays the persistent residues of non-capitalist economic forms mediating the geographies of everyday life (see Gibson-Graham 1996/2006; for a counter-critique see Das 2017). Consequently, the posited strength of fostering capital-centric analysis championed by the social property relations approach becomes its key weakness (Post 2011: 2). The problem therein is that all forms of economic geography and political economy are subjugated by and subsumed into the dynamics of capitalism (see Hesketh 2016). However, taking seriously the tendentially uneven geographical development and spatial expansion of capital confronted by place- and spacebased processes of struggle should also entail recognition of alternative forms of economic 
activity. The social property relations totalising view of capitalism therefore marginalises a plethora of subsistence economic geographies that are often a pillar of the capital-wage labour relation. As a result, Doreen Massey's pivotal reminder to economic geographers that the world is not simply the product of the requirements of capital becomes obscured (Massey 1984/1995: 7, 87).

The third major quandary that bedevils the social property relations approach and its mantra-like abstractions on capitalist imperatives is its consideration of "extra-economic" identities. Whereas it is entirely fitting to articulate that the disappearance of class inequalities . . . is by definition incompatible with capitalism' (Wood 1995: 259), there is a set of much more problematic assertions buried within the topography of social identities, human emancipation, and capitalism. At first blush it may seem reasonable to contend at an abstract level that capitalism is 'uniquely indifferent' to the social identities of the people it exploits and their particular individualities (Wood 1995: 266; see also Bieler and Morton 2018: 147; or Giménez 2019: 34, 100). But capitalism is not gender indifferent. The notion that capitalism is indifferent to the oppression or exploitation of women only holds, if at all, at a high level of abstraction and, from the point of view of concrete history, has highly questionable validity (Arruzza 2014: 11-13). Marx's sophisticated point on this in Grundrisse is that 'since capital as such is indifferent to every particularity of its substance' then 'the labour which confronts it likewise subjectively has the same totality and abstraction in itself' (Marx 1857-8/1973: 296). But in wider commentaries this stance on capital and, subsequently, capitalism's indifference to how production unfolds requires questioning. For example, returning to Marx, Michael Clare Roberts reiterates the case of Mary Anne Walkley in the chapter on the working-day from Capital, Volume 1. The suffering and death of Mary Anne Walkley, he argues, did not result from her own individuality but rather from the circumstances that attended her labours, ensuing from capitalist exploitation and her role qua labourer. Hence the reassertion that the aim of capital-the realisation of surplus value-is indifferent to the particular aim of the labour on which it depends' (Roberts 2017: 126). With 
a similar echo, Moishe Postone (1993: 281, emphasis added) has argued that, 'Marx's analysis of the process of production seen as a process of creating value provides an initial logical determination of the indifference, structurally implicit in capitalism, toward the production of specific products'. Nevertheless, demanding more Marxist Feminist curiosity into the historical and contemporary gendered and racialised ordering of economic geographies is surely required here. This is so because it is incorrect to enforce the monochromatic viewpoint that whereas class is constitutive of capitalism, wider "extra-economic" gendered and racialised inequalities are not (Wood 1988: 6; Wood 1995: 259). Hence when Marx (1849/1977: 211) conjectures in Wage Labour and Capital that 'What is a Negro slave? A man of the black race. The one explanation is as good as the other. A Negro is a Negro. He only becomes a slave in certain relations', he misses the explicit racialisation process. As Cedric Robinson (1983/2000: 81-2) argues, the "Negro" is itself a construct that became an exploitable source of slavelabour power and colonisation prior to becoming centrally constitutive to racial capitalism. Similarly, Angela Davis (1981/2019: 3, 82) emphasises how the slave system defined Black people as chattel, subsequently resulting in 'the tautological definition of Black people as servants [that] is indeed one of the essential props of racist ideology'. Hence, racial domination and gender oppression are constituent underpinnings in the making of capitalism and a Marxist Feminist curiosity or raced-market frame would immediately and easily reveal the specification of such relations of racialised and gendered power as class relations (Federici 2004: 14; Gilmore 2007: 237-9; Tilley and Shilliam 2018: 537-8).

Returning to Marx, then, the death of Mary Anne Walkley in 1863 from 'simple overwork' should be revisited. For doing so, would reveal a much more complex intertwining of expropriative practices of concrete labour. Not all labourers are alike, for Mary Anne Walkley is presented as a white slave, officially deceased due to apoplexy, but whose conditions of labouring constantly for more than 26 hours was due as much to garment making for the guests at a ball given by the Princess of Wales; or the gendered working conditions of consumption, undernourishment and malnutrition; or the forced supply of alcohol to her and 
other women to sustain their failing labour-power; or the demand for needlewomen (over men) to 'conjure up magnificent dresses for the noble ladies', rather than simply over-work and overcrowding within the capitalist specificities of the millinery industry (Marx 1867/1990: 364-5). This alternative reading starts to provoke one to reveal the coercive underbelly of capitalist value creation' and violence, without the cost of gender-blindness (Ferguson 2020: 121). Hence to hold that there is no specific structural necessity for gender oppression in capitalism, or to evade the structural ways that capitalism has specific racialised antagonisms and ruptures, would reinforce an impoverished attendance to conditions of class struggle. Yet this is the central contention at the heart of the social property relations position on social reproduction. Focusing on the abolition of class, Wood argues, means harnessing the material class interests of labour to the popular power of peace, ecological and the 'caring society' concerns of gender politics so that such social movements 'can be forged into forces for socialism by their intersection with the interests of the working class' (Wood 1986: 198, 199, emphasis added). Only if the exigencies of basic human interests-such as ecological disaster or a 'caring society'-become great enough to override other social determinations of class ascription will, it is conceded, a creative force then emerge that can threaten the prevailing order (Wood 1986: 173-6). As Tithi Bhattacharya (2017c: 87, 89) endeavours to clarify, 'in the abstract, capital is indifferent to the race, gender, or abilities of the direct producer, as long as her or his labour power can set the process of accumulation into motion'. Yet, at the same time as she also accepts, 'the process of accumulation thus cannot be indifferent to social categories of race, sexuality, or gender but seeks to organise and shape those categories, which in turn act upon the determinate form of surplus labour extraction'. The full socialisation of the costs of unpaid labour in the household-in terms of care work undertaken within the family-would require means beyond the capitalist system (Harman 1984). As put succinctly by Raj Patel and Jason Moore (2018: 135): 'To ask capitalism to pay for care is to call for an end of capitalism'. This is why the position that capitalism is structurally indifferent to gender (or race) and could survive the eradication of such "extra-economic" oppressions- 
meaning that a world of full gender equality or racial equality would be feasible within capitalism-is untenable.

To sum up this section, the signal contribution of the social property relations approach is its understanding of the historical specificity of the rise of agrarian capitalism and its ideology of improvement in shaping land and people as a commodity. As a result, it has come to focus on how surplus extraction through market dependence and the imperatives of competition, accumulation, profit maximisation and increasing labour-productivity in "civil society" are spatially differentiated from the political coercion of "state" power. Capitalism was "born into" an anterior states-system and conditions of class exploitation are perpetuated through the institution of the modern state, as a capitalist state form, to reproduce capitaliststates. This emphasis on the spatial difference between the economic and the political, however, comes at a cost in relation to the concrete historical reality of capitalism. Emphasising wage labour as the primary form of exploitation in capitalism underpinning this separation should not make us overlook the various other forms of exploitation, which have continued to co-exist with wage labour. This includes racialised conditions of forced labour; alternative, non-capitalist forms of subsistence production; as well as unpaid labour in the household and the wider sphere of social reproduction. When it comes to patriarchal forms of oppression, there is in particular no grasp of how capitalism was "born into" a prior system of patriarchy to recognise how capitalism perpetuates patriarchy, through capitalist-patriarchy (Hartman 1979: 13; Mies 1986/2014: 37-8). This nexus of capitalist-patriarchy to denote women's exploitation and oppression as constitutive and internally related to the social and sexual division of labour within capitalism and its link to struggles against the domination of nature and decolonisation, more broadly, now merits more detailed examination. The next section explores how the internal relations between capitalist exploitation and patriarchal oppression can be conceptualised through a capitalist-patriarchy nexus. Analyses of the historical emergence of capitalism as well as conceptual reflections reveal how gender oppression is a central constitutive underpinning in the making of capitalism, thereby 
acquiring a structural necessity. Importantly, our aim is not to dismiss the social property relations approach and replace its analysis of the emergence of capitalism with an alternative reading. Instead, we intend to demonstrate how the social property relations approach can be extended so that it is able to incorporate a focus on this capitalist-patriarchy nexus.

\section{The capitalist-patriarchy nexus and ongoing primitive accumulation}

In her book Caliban and the Witch (1998/2014), Silvia Federici makes the important claim that the medieval witch-hunt across Europe constituted part of the process of primitive accumulation, preparing the ground for the emergence of capitalism. While the enclosures put an end to people's access to the commons, the witch-hunt resulted in the loss of women's control over their bodies. 'The witch-hunt deepened the divisions between women and men, teaching men to fear the power of women, and destroyed a universe of practices, beliefs, and social subjects whose existence was incompatible with the capitalist work discipline, thus redefining the main elements of social reproduction' (Federici 1998/2014: 165). In other words, the witch-hunt was an essential aspect of the establishment of capitalist social relations of production. 'There is no doubt that in the "transition from feudalism to capitalism" women suffered a unique process of social degradation that was fundamental to the accumulation of capital and has remained so ever since' (Federici 1998/2014: 75). The control of women and their bodies became a direct part of capitalist accumulation. 'The female body, the uterus, [was placed] at the service of population increase and the production and accumulation of labour-power' (Federici 1998/2014: 181).

This is a powerful interpretation of the role of the witch-hunt in medieval Europe in subjecting women to patriarchal forms of oppression. Most pivotally, it addresses accounts of primitive accumulation based on the notion that the emergence of capitalism was a development internal to English agrarian capitalism with its own self-perpetuating dynamic of economic development and agricultural improvement based on a gender-blind 'triad' of landlord, capitalist tenant, and wage-labourer (Brenner 1985: 46-54; Wood 1991: 53-4). 
Despite this pivotal corrective, though, the same analysis of the witch-hunt is perhaps less adept at attending to the spatially diverse and uneven geographical development of capitalism across Europe. This can be revealed by drawing attention to the pan-capitalist thesis at the core of the witch-hunt argument, referring to its geographically simultaneous (rather than unevenly differentiated) account of the onset of capitalism and how the practices of capitalism are assumed to be nested within commercial market relations. For example, it is argued that 'by the late Medieval Ages, wherever we turn, from Tuscany to England and the Low Countries, we find the bourgeoisie already allied with the nobility in the suppression of the lower class' (Federici 1998/2014: 50). The witch-hunt became a unifying terrain in the politics of new European states (Federici 1998/ 2014: 169). Hence it is accepted that the witch-hunt occurred simultaneously across Europe as an essential aspect of primitive accumulation and the "transition" to capitalism (Federici 1998/2014: 164-5). However, rather than part of the emergence of capitalism and some form of primitive accumulation, should the witch-hunts be differentially understood as an internal response to the crisis of feudalism? As Federici outlines herself, the Black Death of the mid-fourteenth century had decimated population levels across Europe so that some peasants became empowered. 'For a broad section of the western European peasantry, and for urban workers, the fifteenth-century was a period of unprecedented power', writes Federici. 'Not only did the scarcity of labour give them the upper hand, but the spectacle of employers competing for their services strengthened their sense of self-value, and erased centuries of degradation and subservience' (Federici 1998/2014: 46-7). Emboldened by their new-found strength, heretic movements started to challenge the nobility's power and oppose the direct coercive force of feudalism. 'Throughout Europe, vast communalistic social movements and rebellions against feudalism had offered the promise of a new egalitarian society built on social equality and cooperation' (Federici 1998/2014: 61). In sum, the witch-hunt might be regarded as less part of the concurrent emergence of capitalism across Europe, and more as a set of uneven and differentiated geographical developments that preceded it. The outcomes of these processes in terms of primitive 
accumulation was nevertheless the emergence of the family as the most important institution for the appropriation and concealment of women's labour (Federici 1988/1994: 97, 115). Thus, just as capitalism was "born into" a prior states system then so too was capitalism "born into" a prior system of patriarchal oppression. In other words, from the very beginning patriarchy has been part and parcel of capitalist exploitation and throughout history has also been re-shaped by it. Therefore, in contrast to the social property relations approach, Mies (1986/2014: 38) argues:

it is my thesis that capitalism cannot function without patriarchy, that the goal of this system, namely the never-ending process of capital accumulation, cannot be achieved unless patriarchal man-woman relations are maintained or newly created . . . Patriarchy thus constitutes the mostly invisible underground of the visible capitalist system.

In concrete terms, "'capitalism" as a simple abstraction does not actually exist. There is only concretely racialised, patriarchal, colonial capitalism, wherein class is conceived as a unity of the diverse relations that produce not simply profit or capital, but capitalism' (Ferguson 2016: 47). Patriarchal oppression may not be a logical precondition for capitalism, but due to the concrete historical emergence of capitalism it is certainly a necessary consequence (Arruzza 2015: 7). The challenge, then, is to conceptualise the internal relations between the exploitation of labour power in commodity production with patriarchal forms of oppression in processes sustaining capitalist accumulation. As Lise Vogel (1983/2013: 146) makes clear, in order to continue with the accumulation of surplus-value, capitalism depends on the generational replacement of the workforce based on biological reproduction. 'It is the provision by men of means of subsistence to women during the child-bearing period, and not the sex-division of labour in itself, that forms the material basis for women's subordination in class-society' (Vogel 1983/2013: 153). The exact way this is institutionally organised within capitalism depends on class struggle, but this particular part of domestic labour is at the heart of the internal relations between patriarchal oppression and capitalist exploitation. This underlines the importance of tracing the inner connections of the social reproduction of class relations among patterns of primitive accumulation, dispossession, capital flows, migration, 
racialisation and gender relations in constituting market-dependent social reproduction (Ferguson and McNally 2014: 2).

The concept of the "social factory" speaks to these themes by including the spheres of production as well as social reproduction and has emerged as an important factor within Marxism Feminism to assess the particular way that capitalist exploitation is internally related to patriarchal forms of oppression. It was Mario Tronti (1966/2019: 27-30) who referred to how society becomes an articulation of the relations of production so that 'the whole society lives in function of the factory and the factory extends its exclusive dominion over the whole society'. Harry Cleaver, too, has similarly contributed to recognising the social factory of capitalism where 'all traditional distinctions between economic and political power disappear' (Cleaver 1979/2000: 70-3; Cleaver 2017: 60). Importantly, unlike the social property relations approach, a focus on the social factory does not reduce capitalist accumulation to the exploitation of wage labour in commodity production. Rather, it recognises how capitalist accumulation is gendered and depends on the whole social factory, including unpaid labour in the sphere of social reproduction. The social factory emphasis is thus a pivotal dimension of Marxism Feminism and its conceptualisation of the capitalist-patriarchy nexus. Mariarosa Dalla Costa (1972/2019: 27-43) most famously developed the notion of the social factory as an organisational form of the reproduction of labour-power to recognise domestic work as not only producing a use value but also as essential to the production of surplus-value. Similarly, Leopoldina Fortunati (1981/1995: 114) recognised the spatial fix of the household to appreciate how capital builds factories both within the process of production and also within the process of reproduction in the 'dispersed factory' of the household. As a consequence, there is a restructuring of the 'social productive body' through the social factory so that 'capital predominates within all family exchanges and relations, making them the exchanges and relations of production of the commodity, labour-power' (Fortunati 1981/1995: 129). Others point out that the reproduction of workers depends not only on wage labour but, equally importantly, on unpaid labour in the sphere of social reproduction. Workers need to earn a 
wage in order to buy the goods necessary for their survival, but they also need someone to cook meals, look after children, wash and mend clothes. Hence, capitalist accumulation must be understood as a social system including both the spheres of production and social reproduction. As Tithi Bhattacharya (2017b: 2) writes, the relations between labour dispensed to produce commodities and labour dispensed to produce people [are] part of the systematic totality of capitalism'. Thus, the main focus is on the internal relations between class and gender, based on an understanding of the capitalist social factory, which includes the spheres of production as well as reproduction. 'To speak of a social whole dominated by the capitalist dynamic-a capitalist social formation-is not to say that the economic wagelabour relationship unilaterally causes racial or gender oppression. It is to suggest, rather, that all social relations are integral to a complex social formation, which is broadly organised in accordance with capital's drive for accumulation and profit' (Ferguson 2016: 56). This means that the social relations of gender, race and sexuality are held as internally constitutive of class, rather than external to it. Thus, such conditions of emergence are understood as always-already present 'moments', or internally-related aspects of the same whole, which exist organically as a unity-in-diversity. Perhaps this is why the claim has been newly reaffirmed that social reproduction theory is therefore unique in its sensitivity towards theorising the relationship between the market and "extra-economic" relations of power, rather than simply gesturing toward their dualist distinction (Bhattacharya 2017b: 14).

While there is broad agreement amongst Marxist Feminists about the need to analyse the way capitalist accumulation depends on the whole social factory, different routes arise to what we recognise here as a value-theory of reproductive labour. These different routes to a value-theory of reproductive labour revolve around the question as to whether unpaid labour in the household directly produces surplus-value or whether it simply facilitates the creation of surplus-value in commodity production. In the next section, we unravel these different routes to a value-theory of reproductive labour. First, we address a set of Marxist Feminist contributions that uphold the categories of productive labour as value-creating and 
reproductive labour as non-value creating, or production/value and reproduction/non-value. This is followed by exploring a group of Marxist Feminists that proffer an alternative route to a value-theory of reproductive labour, from the viewpoint that a chain of value-generating mechanisms exists in the social factory that transcends the productive/unproductive labour dichotomy.

\section{Different routes to a value-theory of reproductive labour}

Marx was clear in his assessment of capitalist accumulation that we have to go beyond the noisy surface appearances of the economy to analyse the concealed sphere of production, if we want to understand exploitation and the extraction of surplus-value. As Marx reminds us, we need to investigate the 'hidden abode of production, on whose threshold there hangs the notice "No admittance except on business". Here we shall see, not only how capital produces, but how capital is itself produced. The secret of profit-making must at last be laid bare' (Marx 1867/1990: 279-80). Importantly, Marx distinguishes between necessary and surplus labour. Necessary labour refers to the part of the working day for which workers receive a wage in order to buy the means for their social reproduction. The rest of the day constitutes surplus labour, during which workers are not paid and, therefore, create surplus-value for capital. It is surplus-value that represents workers' exploitation in the capitalist production process. This exploitation through the commodity production of unpaid labour is masked by the wage-form, which 'extinguishes every trace of the division of the working day into necessary labour and surplus labour, into paid labour and unpaid labour. All labour appears as paid labour' (Marx 1867/1990: 680). The question which bedevils Marxist Feminist approaches is thus the role of unpaid labour in the sphere of social reproduction. Does it also produce surplus-value?

A Marxian strand of social reproduction theory identifies a strict division between labour-power as productive of surplus-value and unpaid domestic (or unproductive) labour as not producing surplus-value (Bhattacharya 2017c: 214n.14; Ferguson 2020: 130). Drawing on Michael Lebowitz (1992/2003), Bhattacharya distinguishes two related, yet separate 
circuits in this respect underpinning capitalist accumulation, the capital-circuit and the wage labour-circuit. 'Within capital's circuit, labour power is a means of production for capital's reproduction, or valorisation. But within wage labour's circuit, the worker consumes commodities as use values (food, clothing, housing, education) in order to reproduce herself. The second circuit is a process of production of self for the worker or a process of selftransformation' (Bhattacharya 2017c: 81). Of course, the possibility of the capital-circuit depends on the wage labour-circuit, but the latter is focused on the production of use values outside the direct control of capital (Ferguson et al., 2016: 30). In other words, unpaid labour in the sphere of social reproduction is essential or necessary for capitalist accumulation in that it enables wage labour in commodity production and, thus, indirectly contributes to surplus-value creation. The more use value for the social reproduction of workers is produced by unpaid labour in the sphere of social reproduction, the smaller the necessary labour part and the higher the surplus labour part of wage labour. We can understand this in relation to 'how housework contributes to increasing surplus-value by lowering the value of labour power, by reducing the amount of commodity-producing labour that must be allocated to those consumer goods necessary for the production and reproduction of labour power (Cleaver 2017: 83n.22). In short, reproductive, unpaid labour is essential labour, and hence important for capitalist accumulation, but itself is unproductive in that it does not produce surplus-value. 'Because value is determined in producing goods for exchange, and insofar as the products of social reproductive labour have in fact been consumed in the creation and sustenance of life (not capital), that labour cannot be ascribed a capitalistic value. It is "unproductive" in capitalist terms' (Ferguson 2020: 125). Critics may recoil from describing unpaid work in the sphere of social reproduction, predominantly performed by women, as unproductive labour. However, to associate the attribution with a demeaning connotation would be to misunderstand Marx's own terminology. Afterall, Marx makes a careful distinction between the spheres of production and the sphere of circulation. Surplus-value is produced in the sphere of production by exploiting wage labour, while it is realised in the sphere of circulation. 
Surplus-value can only be reaped if commodities are actually sold in the market. Hence, any wage labour employed in the sphere of circulation, though essential, is equally unproductive of surplus-value and comes at a cost to surplus-value. In Marx's own words:

The general law is that all circulation costs that arise simply from a change in form of the commodity cannot add any value to it. They are simply costs involved in realising the value of transferring it from one form into another. The capital expended in these costs (including the labour it commands) belongs to the faux frais of capitalist production. The replacement of these costs must come from the surplus product, and from the standpoint of the capitalist class as a whole it forms a deduction of surplusvalue or surplus product (Marx 1884/1992: 225-6).

Thus, bookkeepers and clerks involved in the selling of commodities perform unproductive labour as do storage workers, stock-piling commodities until they can be sold on the market. The money for their wages has to be deducted from the surplus-value generated in production (Marx 1884/1992: 212). Wages for workers in the sphere of circulation 'is then the same as if more necessary labour were used in the direct production process. Only the actual circulation costs increase the value of the product, but decrease the surplus-value' (Marx 1857-8/1973: 548, original emphasis). In other words, it is not only unpaid labour in social reproduction that is unproductive of surplus-value but also a whole range of other functions of paid labour in the capitalist mode of production. As Ferguson (2020: 126) makes clear, 'value creation is understood to require both forms of labour, those that are capitalistically "productive" and those that are not. The latter comprises socially necessary unpaid social reproductive work and different forms of paid labour-public sector social reproductive labour as well as other work that is, according to Marx, essential but not directly "productive"'. In short, describing the unpaid labour of social reproduction as unproductive adheres to the route that Marx delivers as to where exactly surplus-value is created within the various circuits of capitalist accumulation.

For autonomist Marxist Feminists, however, this is a traditional Marxist viewpoint that results in a separation of production as the creation of surplus-value from reproduction as non-value generating. Acceptance of this dualism then results in the replication of surplusvalue fairy tales (Fortunati 1981/1995: 70). It falls into the same trap as Ellen Meiksins Wood 
in identifying rigid, binary separations and is, therefore, unable to account properly for the structurally necessary role of gendered forms of exploitation within capitalist accumulation. For Maria Mies (1986/2014: 110), in other words, the 'proletarianisation of men is based on the housewifisation of women'. Failure to recognise this intrinsic relation separates the question of social reproduction (in terms of labour-power) from the reproduction of capitalist society (in terms of value generation) to de-emphasise the role of the household in the reproduction of capitalist society as a whole (Munro 2019: 465). The challenge for this second set of Marxist Feminists, then, is to assert the inner character and substance of social reproductive labour as value-creating within the capitalist-patriarchy nexus as constitutive of commodities but without replicating a further binary dualism. One advance is to engage in a more expansive reading of Marx on the value question and the multiple meanings of reproduction. For example, statements such as value 'brings forth living offspring, or at least lays the golden egg', to recognise that, 'both paid and unpaid labour create value and enter the commodity as elements of value formation' could be unpacked more from an autonomist Marxist Feminist viewpoint (Marx 1867/1990: 255; Marx 1894/1991: 133). After all, building on Diane Elson, the method of historical materialism is to go inside the form of the commodity, to delve beneath apparent appearances, and to take account of the ever-widening spiral movement of capital. For Elson, this results in a value-theory of labour that strives to address the substance of value in the social metabolism of human activity in interaction with nature and commodities that transforms concrete labour into an expression of abstract human labour (Elson 1979: 158-60). 'This intertwining, however,' as Marx (1884/1992: 193) recognised, 'is not by this token alone an entwining of the metamorphoses of capital'. It is this method of abstraction that would aim to transcend a logic of bifurcation between productive sectors (setting in motion value and surplus-value) and unproductive sectors (that do not add to the sum total of social value and surplus-value produced). By extension, a more expansive valuetheory of reproductive labour would assert how the spiral movement of capital directly and indirectly connects social reproductive labour to value-production in order to recognise that 
the substance and social metabolism of social reproductive work is intrinsic to valueproduction. This raises the relevance of a value-theory of reproductive labour to everyday spaces of living and producing in capitalism.

A key contribution to transcending the duality of spatially separate spheres of production/value and reproduction/non-value has been made by Leopoldina Fortunati. In The Arcane of Reproduction she presents a dialectical understanding of how capital valorises itself through production and reproduction by relating the categories intrinsically. Although in its forms of appearance capitalism presents itself so that waged-work in production appears as the creation of value and non-waged work within the household appears as non-value generating, there is an internal relation to these realms connected through a focus on labourpower. As argued elsewhere, what can then be fully revealed is, 'the physical materiality inherent to the constitution and daily reproduction of social relationships which require our body to be sold on the labour market in order to receive an income and thus survive; that is the compulsion to be a commodity' (Bruff 2013: 73). For Fortunati, in capitalism, social reproduction is posited as a "natural" force of social labour that costs capital nothing. This returns us to Marx who argued that there are "natural" elements that enter into production which seemingly cost capital nothing, as 'a free gift of Nature to capital', but the capital relation that then arises proceeds as 'a gift, not of nature, but of a history embracing thousands of centuries' (Marx 1867/1990: 647; Marx 1894/1991: 879). Hence, for Fortunati, labour power has a twofold character: 1) the first face confronts capital as a commodity based on exchange-value; and 2) the second face appears as a non-commodity, as a pure use value or "natural" force of social labour, but actually reproduces itself as value within the process of reproduction (Fortunati 1981/1995: 11-13). There emerges an intrinsic, necessary relationship between these two faces of labour power that moves beyond the surface forms of appearance to connect them as constitutive of value-production. In sum, Fortunati accepts the apparent dualism that capitalism presents to us-production/value and reproduction/nonvalue-but intrinsically connects them because capital confronts the commodity of labour 
power and its exchange-value by also drawing on its free, cheap, or "natural" gift of social reproduction. In so doing, the chain of value-creation is created and the binary dualism of productive/unproductive labour is broken. That is why 'this duality allows the capitalist mode of production to function at a much higher level of productivity than could be attained in any of the preceding modes of production' (Fortunati 1981/1995: 9).

One of the roles of reproductive labour under capitalism is to raise the use-value of the male worker's labour-power, regarded as directly productive for capital. Unpaid social reproductive labour-housework, or care-giving for the young and elderly alike-is therefore of a piece with commodity production and value-creation. Like any other commodity there is a unity to the process of producing and reproducing labour-power and thus the process of value-formation. As Federici reminds us, 'the time we consume in the "social factory", preparing ourselves for work or going to work, restoring our "muscles, nerves, bones and brains" with quick snacks, quick sex, movies, all this appears as leisure, free time, individual choice' (Federici 2012: 35-6, quoting Marx 1867/1990: 717). But housework, or unwaged reproductive work more broadly, is just as constitutive of abstract labour and value-formation as wage-labour, regardless of the fact that it is produced for its use-value rather than for exchange-value (Fortunati 1981/1995: 79, 81). After all, the exchange-value of labour power contains both socially necessary labour time as well as the socially necessary domestic labour time required to produce the labour power itself (Fortunati 1981/1995: 84; see also Vogel 1983/2013: 192-3; Giménez 2019: 247-8, 266). Set in motion, then, is the "double somersault" that capital enacts as exploitative of both production and social reproduction as part of the valorisation process (Fortunati 1981/1995: 82). Crucially, as a result of this focus on the realms of value-generation and how it captures the majority of labourers under contemporary capitalism, a plethora of invisibilised economic activities that often are actually a pillar of the capital-wage labour become apparent. Alessandra Mezzadri (2020: 158-9; 2021) identifies three particular channels through which this takes place: 1) the reenforcement of patterns of labour control in dormitories outside the work place; 2) the role 
of intergenerational reproductive realms in the rurality of developing countries that secure the future work force; and 3) the formal subsumption of homeworkers under capitalist accumulation, who are predominantly women. This wider intrinsic consideration of valueproducing work thus affirms the significance of women's unpaid reproductive work in the process of capital accumulation and the wider web of nature. It also connects the unity of appropriation and "extra-economic" violence through the prevalence of forms of directly coerced (or unfree) labour within contemporary capitalism (Mies and Bennholdt-Thomsen 2000: 31-2; Salleh 1997/2017; Moore 2015: 98).

By contrast, Cinzia Arruzza (2014: 16) is highly critical of such autonomist Marxist Feminists for conceiving the unity between production and social reproduction as a direct identity. 'Such a point of view', she argues, 'returns to a form of reductionism, which obscures the difference between various social relations and does not help us understand the specific characteristics of diverse relations of domination that are not only constantly reproduced but also transformed within each capitalist social formation'. The statement by Silvia Federici (2019: 56) 'that to deny the productivity of unpaid work activities is to assume that much of the world population is irrelevant to capital accumulation, which means that it cannot make the claim that the wealth that capitalism produces is also the fruit of its labour' is, therefore,

incorrect. What emerges is a division between these two routes to a value-theory of reproductive labour and the precise meaning of surplus-value, but not whether unpaid reproductive labour is essential for capitalist accumulation or not. The implications of this division, however, go beyond a simple theoretical disagreement over how to define surplusvalue production. The direct consequence is also political in terms of how to engage conditions of resistance beyond the requirements of capital, which we now turn to in conclusion.

\section{Conclusion: calling on capitalism to pay for social reproduction}

As a summary, among the signal contributions of the social property relations approach are, first, its understanding of the historical specificity of capitalism and how surplus extraction 
through market dependence and the imperatives of competition, accumulation, profit maximisation and increasing labour-productivity in "civil society" are spatially differentiated from the political coercion of "state" power. The second pivotal contribution to a social history of political thought is how these economic imperatives were grounded in an ideology of improvement-linked to early-modern economic theory from William Petty to John Locke onwards - that fuses together an understanding of the value of land and people as a central component of the origins of capitalism. Aside from the elements of critique in the form of the quandaries we have raised, the social property relations approach is pivotal in asserting how the imperatives of capitalism and its ideology of improvement were "born into" an anterior states-system and perpetuated along uneven and combined developmental lines through the institution of the modern state, as a capitalist form, to reproduce capitalist-states. Nevertheless, there is no grasp within social property relations arguments of how capitalism was "born into" a prior system of patriarchy to recognise how capitalism is gendered through capitalist-patriarchy. In practice, as we have argued, calling on capitalism to pay for social reproduction would also be a call for an end to capitalism, given the gendered architecture of the "social factory" as a social space and the internal relation between the role of unpaid labour in the household and its purpose in reproducing labour power, physically, emotionally and sexually for capital. It is therefore patently incorrect to state that gender struggles are not 'fatally dangerous to capitalism' (Wood 1988: 8).

Struggles over reproductive work and the restructuring of housework are a major social justice dispute that can be spotlighted by our emphasis on a value-theory of reproductive labour as part of imagining a postcapitalist world across contending routes within Marxism Feminism. For Marxian social reproduction theorists a value-theory of reproductive labour draws out the traditional Marxist conception of productive labour (as value-producing) and unpaid reproductive labour (as non-value generating) but mediated by attempts to reduce the cost of socially necessary labour time. Profit-making and people-making are held extrinsically, as analytically distinct, but nevertheless mutually constitutive (Arruzza, 
Bhattacharya, Fraser 2019: 70). Hence, the criticism by autonomist Marxist Feminists that this route to social reproduction theory remains trapped within the "indifferent capitalism" thesis of the social property relations approach due to its reliance on binary thinking (see Farris 2015; and Arruzza 2015 for the rejoinder). Thus, for autonomist Marxist Feminists, capital valorises itself through both the production and reproduction of labour-power, which is understood by relating such categories intrinsically. The dualism of production/value and reproduction/non-value is a form of appearance that capitalism presents to us and requires transcending in order to establish the totalising form of commodity-determined abstract labour as intrinsic to the character of capitalism. 'Capital's message to the proletariat is that the only purpose of life is work' (Fortunati 1981/1995: 162). As Silvia Federici (1998/2014: 14) powerfully clarifies, 'if "femininity" has been constituted in capitalist society as a workfunction masking the production of the work-force under the cover of a biological destiny, then "women's history" is "class history"'.

The focus on reproductive or caregiving labour opens up questions about how unwaged reproductive labour and, more generally, the spatial fix of households might also be mobilised as sites of activism or counter-spaces to the structuring of value. On one hand, autonomist Marxist Feminists emphasise the all-encompassing nature of capitalism. According to Fortunati (1981/1995: 129, 159), 'capital predominates within all family exchanges and relations, making them the exchanges and relations of the production of the commodity, labour-power' and thus 'capital usurps not only free time, but also that part of necessary reproduction work time that appears as non-work time'. As a result, rather than resisting inside capitalism, the focus is on building autonomous structures and alternative forms of living in parallel to existing capitalist social and power relations. Only once we are outside capitalism, can we establish new ways of living and producing. Yet, in a peculiar reminder of the earlier critique we developed of the capitalocentric social property relations approach, the world is not simply the product of the requirements of capital (Massey 1984/1995: 7, 87). Households should therefore not be regarded as mere functional units geared towards the 
dictates of capital accumulation (Rioux 2015). The corollary is that there tends to be a totalising tendency at work in viewing all reproductive labour as value-producing, so that postcapitalist feminist struggles become difficult to perceive from this autonomist Marxist Feminist approach to a value-theory of reproductive labour. 'It fails to highlight the potentialities of mass movement building across productive and reproductive sectors for forging new ways of life-making while also confronting capital on its own terrain' (Ferguson 2020: 130). By contrast, rather than a one-dimensional concept of abstract labour dominating under capitalism, the Marxian value-theory of reproductive labour discussed above holds that 'capital never manages to instrumentalise labour, to liquidate its qualities of sentient, desiring, thinking being' (McNally 2004: 202-3). The unpaid work of social reproduction is, according to this view, to some extent outside the direct control of capitalism, facilitating resistance to market discipline. 'The unpaid work of social reproduction', writes Ferguson, 'is sufficiently "outside" capital to be highly flexible. While performing such labour, many people can, to a significant degree, ignore or resist market disciplining of their lives' (Ferguson 2020: 127). Postcapitalist struggles are therefore immanent to the logic of capital and all forms of labour protest contain spaces of non-capitalism linked to concrete labour. As Ruth Wilson Gilmore (2007: 238-9) has detailed, unwaged reproductive labour can reclaim activism and become central to the frontline struggle against the racialised class politics of the neoliberal state and its attacks on working-class households. The spatial fix of households has become central to the process of cooperative struggle through which mothers have 'transformed their caregiving or reproductive labour into activism' (Gilmore 2007: 183). This viewpoint on resistance, therefore, allows us to conceptualise class struggle against capitalist exploitation broadly across the spheres of production and social reproduction. Strikes in the form of the withdrawal of wage labour can also include 'workplace- and community-based protests for better schools, healthcare, housing, transportation, and environmental protections. And it stresses the importance of building solidarity across such struggles' (Ferguson 2020: 133). Capitalist exploitation, in short, is not only resisted by establishing autonomist structures in parallel to 
capitalism, but also by directly confronting capitalism through the establishment of mass movements based on struggles across the social factory in everyday communities. In sum, the two routes to theorising a value-theory of reproductive labour deliver divergent pathways on the issue of concrete political struggle. Importantly, both routes to a value theory of reproductive labour also deliver on the call for 'seeing value' in a return to the roots of radical feminism within and beyond political economy (Duriesmith and Meger, 2020: 370).

To conclude, for both these routes to a value-theory of reproductive labour and the related consequences for resistance, capitalism is not unassumingly indifferent to the identity of those it exploits as it works through the differentiation of, and discrimination within, the labour force. The argument that capitalism is structurally indifferent to gender, or race, or sexuality, as "extra-economic" identities, is therefore a misnomer. The key future task is to do more work to put the different routes of a value-theory of reproductive labour to work.

\section{References}

Anderson, Perry (1974a) Passages from Antiquity to Feudalism. London: Verso.

Anderson, Perry (1974b) Lineages of the Absolutist State. London: Verso.

Arruzza, Cinzia (2014) 'Remarks on Gender', Viewpoint Magazine (2 September); accessed online https://viewpointmag.com/2014/09/02/remarks-on-gender/.

Arruzza, Cinzia (2015) 'Logic or History? The Political Stakes of Marxist-Feminist Theory', Viewpoint Magazine (23 June); accessed online https://viewpointmag.com/2015/06/23/logic-orhistory-the-political-stakes-of-marxist-feminist-theory/.

Arruzza, Cinzia, Tithi Bhattacharya and Nancy Fraser (2019) Feminism for the 99 Percent: $A$ Manifesto. London: Verso.

Banaji, Jairus (2010) Theory as History: Essays on Modes of Production and Exploitation. Leiden: Brill.

Bhattacharya, Tithi (ed.) (2017a) Social Reproduction Theory: Remapping Class, Recentering Oppression. London: Pluto Press.

Bhattacharya, Tithi (2017b) 'Introduction: Mapping Social Reproduction Theory', in Tithi Bhattacharya (ed.) Social Reproduction Theory: Remapping Class, Recentering Oppression. London: Pluto Press, pp. 1-20.

Bhattacharya, Tithi (2017c) 'How Not to Skip Class: Social Reproduction of Labour and the Global Working Class', in Tithi Bhattacharya (ed.) Social Reproduction Theory: Remapping Class, Recentering Oppression. London: Pluto Press, pp. 68-93.

Bieler, Andreas and Adam David Morton (2018) Global Capitalism, Global War, Global Crisis. Cambridge: Cambridge University Press. 
Brenner, Robert (1985) 'Agrarian Class Structure and Economic Development in Pre-Industrial Europe', in T.H. Aston and C.H.E. Philpin (eds) The Brenner Debate: Agrarian Class Structure and Economic Development in Pre-Industrial Europe. Cambridge: Cambridge University Press, pp. 10-63.

Bruff, Ian (2011) 'Overcoming the State/Market Dichotomy', in Stuart Shields, Ian Bruff and Huw Macartney (eds) Critical International Political Economy: Dialogue, Debate and Dissensus. London: Palgrave, pp. 80-98.

Bruff, Ian (2013) 'The Body in Capitalist Conditions of Existence: A Foundational Materialist Approach', in Angus Cameron, Jen Dickinson, and Nicola Smith (eds) Body/State. Farhnam: Ashgate, pp. 67-84.

de Brunhoff, Suzanne (1978) The State, Capital and Economic Policy [1976], trans. Mike Sonenscher. London: Pluto Press.

Ciccariello-Maher, George (2017) Decolonizing Dialectics. Durham: Duke University Press.

Cleaver, Harry (1979/2000) Reading Capital Politically. San Francisco, CA.: AK Press.

Cleaver, Harry (2017) Rupturing the Dialectic: The Struggle Against Work, Money and Financialisation. Chico, CA.: AK Press.

Dalla Costa, Mariarosa (1972/2019) 'Women and the Subversion of Community', in Mariarosa Dalla Costa (ed.) Women and the Subversion of Community: A Mariarosa Dalla Costa Reader. Oakland, CA.: PM Press.

Das, Raju (2017) Marxist Class Theory for a Skeptical World. Leiden: Brill.

Davis, Angela Y. (1981/2019) Women, Race \& Class. London: Penguin.

Duriesmith, David and Sara Meger (2020) 'Returning to the Root: Radical Feminist Thought and Feminist Theories of International Relations', Review of International Studies, 46(3): 357-75.

Elson, Diane (1979) 'The Value-Theory of Labour', in Diane Elson (ed.) Value: The Representation of Labour in Capitalism. London: Verso, pp. 115-80.

Farris, Sara (2015) 'The Intersectional Conundrum and the Nation-State', Viewpoint Magazine, (4 May); accessed online: https://viewpointmag.com/2015/05/04/the-intersectionalconundrum-and-the-nation-state/.

Federici, Silvia (1998/2014) Caliban and the Witch: Women, the Body and Primitive Accumulation. Brooklyn, NY.: Autonomedia.

Federici, Silvia (2012) Revolution at Point Zero: Housework, Reproduction and Feminist Struggle. Oakland, CA.: PM Press.

Federici, Silvia (2019) 'Social Reproduction Theory: History, Issues and Present Challenges', Radical Philosophy, 2.04: 55-7.

Ferguson, Susan (2016) 'Intersectionality and Social-Reproduction Feminisms: Toward an Integrative Ontology', Review of International Studies, 24(2): 38-60.

Ferguson, Susan (2020) Women and Work: Feminism, Labour and Social Reproduction. London: Pluto Press.

Ferguson, Susan and David McNally (2014) 'Precarious Migrants: Gender, Race and the Social Reproduction of a Global Working Class', in Leo Panitch (ed.) The Socialist Register: Transforming Classes. London: Merlin Press. 
Ferguson, Susan, Genevieve LeBaron, Angela Dimitrakaki and Sara R. Farris (2016) 'Special Issue on Social Reproduction: Introduction', Historical Materialism, 24(2): 25-37.

Fortunati, Leopoldina (1981/1995) The Arcane of Reproduction: Housework, Prostitution, Labor and Capital, trans. Hilary Creek. New York: Autonomedia.

Gibson-Graham, J.K. (1996/2006) The End of Capitalism (As We Knew It): A Feminist Critique of Political Economy, new edition. Minneapolis: University of Minnesota Press.

Gilmore, Ruth Wilson (2007) Golden Gulag: Prisons, Surplus, Crisis and Opposition in Globalizing Capitalism. Berkeley, CA.: University of California Press.

Giménez, Martha E. (2019) Marx, Women and Capitalist Social Reproduction: Marxist Feminist Essays. Chicago: Haymarket.

Harman, Chris (1984) 'Women's Liberation and Revolutionary Socialism', International Socialism, Series 2, No. 23: 3-41.

Hartman, Heidi I. (1979) 'The Unhappy Marriage of Marxism and Feminism', Capital \& Class, No. 8: 1-33.

Hesketh, Chris (2016) 'The Survival of Non-Capitalism', Environment and Planning D: Society and Space, 34(5): 877-94.

International Labour Office (2014) Profits and Poverty: The Economics of Forced Labour. Geneva: ILO.

Lacher, Hannes (2006) Beyond Globalization: Capitalism, Territoriality and the International Relations of Modernity. London: Routledge.

Lebowitz, Michael (1992/2003) Beyond Capital: Marx's Political Economy of the Working Class, Second edition. London: Palgrave.

Marx, Karl (1849/1977) 'Wage Labour and Capital' in Karl Marx and Friedrich Engels, Collected Works, Volume 9. London: Lawrence and Wishart: pp. 197-221.

Mark, Karl (1857-8/1973) Grundrisse, trans. Martin Nicolaus. London: Penguin.

Marx, Karl (1861-63/2000) Theories of Surplus Value. Amherst, New York: Prometheus Books.

Marx, Karl (1867/1990) Capital: A Critique of Political Economy, Volume 1, intro. Ernest Mandel, trans. Ben Fowkes. London: Penguin.

Marx, Karl (1884/1992) Capital: A Critique of Political Economy, Volume 2, intro. Ernest Mandel, trans. David Fernbach. London: Penguin.

Marx, Karl (1894/1991) Capital: A Critique of Political Economy, Volume 3, intro. Ernest Mandel, trans. David Fernbach. London: Penguin.

Massey, Doreen (1984/1995) Spatial Divisions of Labour: Social Structures and the Geography of Production, Second edition. London: Palgrave.

McNally, David (2004) 'The Dual Form of Labour in Capitalist Society and the Struggle over Meaning', Historical Materialism, 12(3): 189-208.

McNally David (2015) 'The Dialectics of Unity and Difference in the Constitution of WageLabour: On Internal Relations and Working Class Formation', Capital \& Class, 39(1): 131-46.

McNally, David (2017) 'Intersections and Dialectics: Critical Reconstructions in Social Reproduction Theory', in Tithi Bhattacharya (ed.) Social Reproduction Theory: Remapping Class, Recentering Oppression. London: Pluto Press, pp. 94-111. 
Mezzadri, Alessandra (2020) 'The Informal Labours of Social Reproduction', Global Labour Journal, 11(1): 156-63.

Mezzadri, Alessandra (2021) 'A Value-Theory of Inclusion: Informal Labour, the Homeworker, and the Social Reproduction of Value', Antipode, 53(4): 1186-1205.

Mies, Maria (1986/2014) Patriarchy and Accumulation on a World Scale: Women in the International Division of Labour. London: Zed Books.

Mies, Maria and Veronika Bennholdt-Thomsen (2000) The Subsistence Perspective: Beyond the Globalised Economy, trans. Patrick Camiller, Maria Mies and Gerd Weih. London: Zed Books.

Moore, Jason W. (2015) Capitalism in the Web of Life: Ecology and the Accumulation of Capital. London: Verso.

Morton, Adam David (2013) 'The Limits of Sociological Marxism?', Historical Materialism, 21(1): 129-58.

Munro, Kirstin (2019) "Social Reproduction Theory", Social Reproduction and Household Production', Science \& Society, 83(4): 451-68.

Ollman, Bertell (1976) Alienation: Marx's Conception of Man in Capitalist Society, Second edition. Cambridge: Cambridge University Press.

Orzeck, Reecia (2007) 'What Does not Kill You: Historical Materialism and the Body', Environment and Planning D: Society and Space, 25(3): 496-514.

Patel, Raj and Jason W. Moore (2018) A History of the World in Seven Cheap Things: A Guide to Capitalism, Nature and the Future of the Planet. Berkeley, CA.: University of California Press.

Postone, Moishe (1993) Time, Labor and Social Domination: A Reinterpretation of Marx's Critical Theory. Cambridge: Cambridge University Press.

Roberts, William Clare (2017) Marx's Inferno: The Political Theory of Capital. Princeton: Princeton University Press.

Robinson, Cedric H. (1983/2000) Black Marxism: The Making of the Black Radical Tradition. Foreword Robin D. G. Kelley. Chapel Hill, NC.: The University of North Carolina Press.

Rioux, Sébastien (2013) 'The Fiction of Economic Coercion: Political Marxism and the Separation of Theory and History', Historical Materialism, 21(4): 92-128.

Rioux, Sébastien (2015) 'Embodied Contradictions: Capitalism, Social Reproduction and Body Formation', Women's Studies International Forum, 48: 194-202.

Salleh, Ariel (1997/2017) Ecofeminism as Politics: Nature, Marx and the Postmodern, Second edition. London: Zed Books.

Sayer, Derek (1987) The Violence of Abstraction: The Analytic Foundations of Historical Materialism. London: Basil Blackwell.

Teschke, Benno (2003) The Myth of 1648: Class, Geopolitics and the Making of Modern International Relations. London: Verso.

Tronti, Mario (1966/2019) Workers and Capital, trans. David Broder. London: Verso.

Vogel, Lise (1983/2013) Marxism and the Oppression of Women: Toward a Unitary Theory. Chicago: Haymarket Books.

Wood, Ellen Meiksins (1986) The Retreat from Class: A New 'True' Socialism. London: Verso. 
Wood, Ellen Meiksins (1988) 'Capitalism and Human Emancipation', New Left Review (I), No. 167 (January-February 1988): 3-20.

Wood, Ellen Meiksins (1991) The Pristine Culture of Capitalism: An Historical Essay on Old Regimes and Modern States. London: Verso.

Wood, Ellen Meiksins (1994) 'From Opportunity to Imperative: The History of the Market', Monthly Review, 46(3): 14-40.

Wood, Ellen Meiksins (1995) Democracy Against Capitalism: Renewing Historical Materialism. Cambridge: Cambridge University Press.

Wood, Ellen Meiksins (2002a) The Origin of Capitalism. London: Verso.

Wood, Ellen Meiksins (2002b) 'Capitalism and Human Emancipation: Race, Gender, and Democracy', in Nancy Holmstrom (ed.) The Socialist Feminist Project: A Contemporary Reader in Theory and Politics. New York: Monthly Review Press, pp. 277-92.

Wood, Ellen Meiksins (2003) Empire of Capital. London: Verso.

Wood, Ellen Meiksins (2006) 'Logics of Power: A Conversation with David Harvey', Historical Materialism, 14(4): 9-34.

Wood, Ellen Meiksins (2009) 'Class, Race and Capitalism: How Does Race Relate to Class? A Debate', https://advancethestruggle.files.wordpress.com/2009/06/how does race relate to class-2.pdf; accessed online.

Wood, Ellen Meiksins (2012) Liberty and Property: A Social History of Western Political Thought from Renaissance to Enlightenment. London: Verso.

Wood, Ellen Meiksins and Neal Wood (1997) A Trumpet of Sedition: Political Theory and the Rise of Capitalism, 1509-1688. London: Pluto Press. 